\title{
The Bivalve Mollusc Abra ovata: Role in Succession of Soft Bottom Communities on Newly Flooded Area of the Caspian Sea
}

\author{
Yuri Ya. Latypov \\ A.V. Zhirmunsky Institute of Marine Biology, Far East Branch, Russian Academy of Sciences, Vladivostok, Russia \\ Email: Itpv@mail.ru
}

Received 19 April 2015; accepted 30 May 2015; published 2 June 2015

Copyright (C) 2015 by author and Scientific Research Publishing Inc. This work is licensed under the Creative Commons Attribution International License (CC BY). http://creativecommons.org/licenses/by/4.0/ c) (7) Open Access

\begin{abstract}
The succession of an Abra ovata community that had formed at the flooded area in Sulaksky Bay (the Caspian Sea) since the mid-1980s was investigated. The resident species Abra ovata and Cerastoderma glaucum, the pioneer settlers, were found remaining dominant in the community structure and driving the course of its succession, despite some decrease in settlement density and in the rate of occurrence. It was the tolerance of the Sulaksky pioneer settlers for later colonists (macrophytes, mytilids, crustaceans and other organisms) that determined the development of the first succession stage. The next succession stage in Abra ovata communities of Sulaksky Bay does not quite agree with the pattern typical of solid substrates. On the one hand, the community development supports the tolerance model: the pioneer $A b r a$, in spite of being dominant through all the succession stages, does not oppose the settling of other multiple colonists; on the other hand, it agrees with a facilitation model where the abundance of the original settlers, the grazing species, provokes appearance of sturgeon.
\end{abstract}

\section{Keywords}

Caspian Sea, Flooded Area, Succession, Bottom Community, Bivalve Mollusc, Abra ovata

\section{Introduction}

The level of Caspian Sea 5 thousand years ago reached the mark of $-20 \mathrm{~m}$ absolute altitude. Even earlier (12 20 thousand years ago), the water level was at elevation $+50 \mathrm{~m}$ and the wavelength was then "grey" Caspian strolled across the foothills of the Caucasus, and the plains of the Valley of the River raised Deep Bay to the mouth of the Kama River. Fixed repeated fluctuations in low and high standing in the sea were from the 
mid-16th century the highest elevation $-22 \mathrm{~m}$ absolute level recorded in 1805. In the beginning of this century, sea level was $-26.2 \mathrm{~m}, 30$ - 40 years $-28.0 \mathrm{~m}$ fall in continued until 1977, and since the beginning of the 20th century was $3 \mathrm{~m}[1]$.

The bivalve mollusc Abra ovata Philippi, 1836 (=Abra segmentatum Recluz, 1873), also known sometimes as Syndesmia ovata, is widespread from the shores of England through the Atlantic Ocean, Mediterranean Sea and up to the Caspian Sea [1]-[8]. Throughout the whole area, this mollusc prefers the waters of 3 to 20 meters deep with soft silt or silty-sand bottoms. Abra ovata is eurythermic and euryhaline. It easily withstands the severe Caspian winter temperatures of as low as $2^{\circ} \mathrm{C}$ and the summer warming of up to $28^{\circ} \mathrm{C}-30^{\circ} \mathrm{C}$. The best salinity range for Abra ovata is 10\% - 25\%; however, mature females, kept in water of $7.5 \%$ o have been observed to produce eggs, which are subsequently fertilized and develop normally [8] [9]. The maximum salinity of 35.5\% $36.9 \%$ at which A. ovata could exist was that recorded in the Portuguese lagoon Ria Formosa [10]. Abra is detrivorous; it feeds collecting food with its siphon from the bottom surface.

Mass reproduction of Abra occurs during early spring and late in the fall, depending on the temperature of bottom waters in its habitat. The mollusk reaches sexual maturity at the age of two years. Abra is very fecund (up to several hundreds of thousands eggs) and has a pelagic larva [8] [11] [12]. Although a variable element of the benthos, Abra is abundant, with high settlement density and biomass indices all throughout the area. Due to a thin shell and high settlement density (several thousand indivs $\mathrm{m}^{2}$ ), this mollusc is a diet (quite often the main one) of a great variety of fishes in all of its habitats [12]-[14].

The first discovery of A. ovata in the Caspian Sea dated back to 1955, after it had been repeatedly transferred from the Azov Sea in 1947-1948 [15]. In the first half of the 1960s, Abra habitats covered all the littoral area in the north, west and south of the Caspian. By that time, molluscs in some regions constituted the bulk of the benthic biomass (up to $500 \mathrm{~g} \cdot \mathrm{m}^{2}$ ), with the dominant Abra density exceeding 2500 indivs $\cdot \mathrm{m}^{2}$ [12]. As a new dweller, Abra gained domination in the Caspian autochthonous biocenoses, occupied different bottom sites and, reaching high number, formed, with other new dwellers (Nereis, Cerastoderma), a number of new natural communities [4] [16].

The next intensive rise in the Caspian Sea level began in 1979. The most conspicuous part of the flooded area was that from Agrakhansky Peninsula to the city of Makhachkala, and particularly in Sulaksky Bay where the sea level rise was in excess of $2 \mathrm{~m}$, shifting the coast line over $1 \mathrm{~km}$ towards the village of Sulak. Thousands of square kilometers of land were flooded and on the most part of new territory sea conditions had already existed for more than 20 years [17] [18]. The analysis of the development of Abra ovata community that began to form on the newly flooded territory was the subject of this paper.

\section{Materials and Methods}

Studies were started in 1994 and continued in 1996, 2001 at the flooded area in Sulaksky Bay. Fifty-one stations on four transects at a depth of 0.1 - 4 m were made using SCUBA (Figure 1). At each transect (station depths of $0.3 ; 0.5 ; 1 ; 2$ and $4 \mathrm{~m}$ ), 3 to 5 samples were collected by using a diver's bottom sampler with the mouth area of $0.025 \mathrm{~m}^{2}$. In 1994 the depth of $0.3 \mathrm{~m}$ corresponded to the year of flooding 1993; respectively: $0.5 \mathrm{~m}, 1991-1992$ years; 1 m, 1985-1986 years; 2 m, 1978-1979 years. The Hydrometeorology Service of Dagestan kindly shared the data on the Caspian Sea level variations since 1978 at the site of Makhachkala depth gauge (Figure 2). The samples were washed on a set of soil sieves, with mill gauze on the last of them. Flora and fauna samples were wet weighed at the sites and dried on filtering paper after separating them into taxonomic groups. Total of 21 macrobenthos taxons, mainly of species level, belonging to 14 genera of invertebrates and 6 to macrophytes, were identified.

\section{Results}

On depth $0.3 \mathrm{~m}$, in one year after flooding (1993), no distinctly identifiable live molluscs A. ovata were discovered, though single shells occurred in the samples. During the second and third years after flooding (1992 and 1991 respectively), at a depth of $0.5 \mathrm{~m}$, Abra formed settlements with an average density of $40 \pm 21.7$ indivs $\cdot \mathrm{m}^{-2}$ and a biomass of $13.4 \pm 7.9 \mathrm{~g} \cdot \mathrm{m}^{-2}$, at an occurrence rate of $40 \%$. The polychaetes Nereis diversicolor were also observed. In the conditions of water level rising and the sea advancing upon the land, depth may be viewed as a function of time, and hence, the succession stages in the community of the flooded area might, with a certain probability, be retraced. 


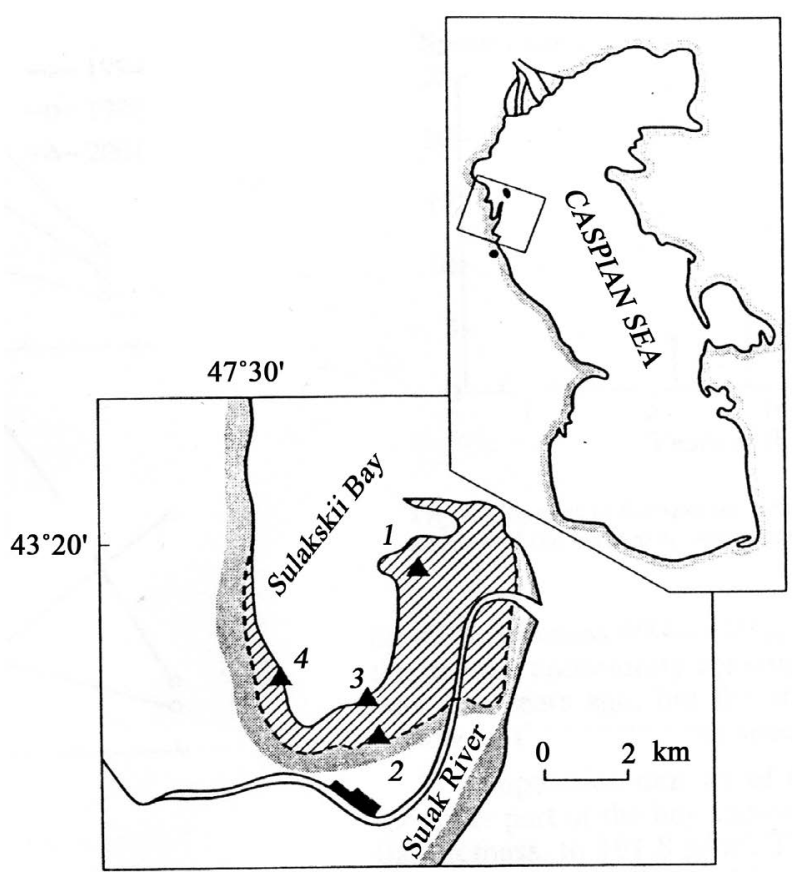

Figure 1. A schematic map of the studied area [1]-[4]. Location of transects; the flooded area is shaded.

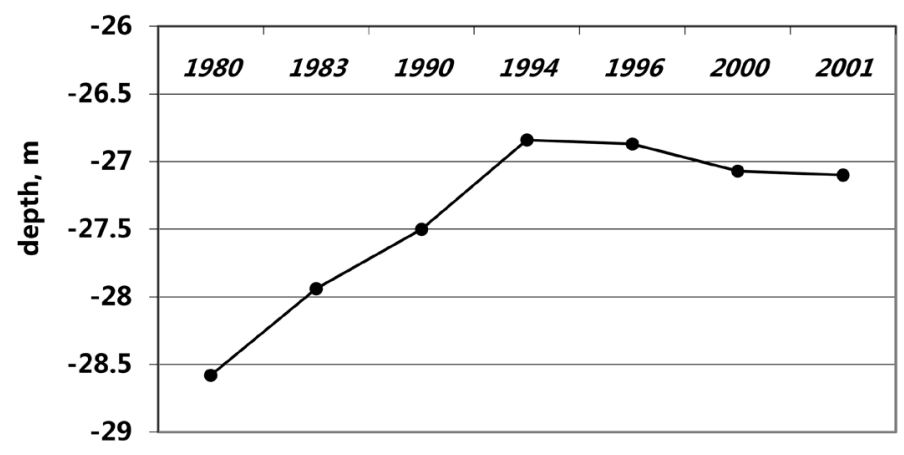

Figure 2. Changes of the level of the Caspian Sea.

During 5 - 6 post-flooding years (1987-1989, depth increased to $1 \mathrm{~m}$ ), the occurrence frequency in Abra ovata grew up to $75 \%$; there was a sharp increase in the average density of up to $296 \pm 47.5$ indivs $\mathrm{m}^{-2}$, at a biomass of $29.1 \pm 3.6 \mathrm{~g} \cdot \mathrm{m}^{-2}$ (Figure 3). The appearance of another mollusc, Cerastoderma glaucum, with an occurrence rate of $20 \%$ was observed.

Early in the 1990s, the depth at the flooded area in Sulaksky Bay reached $2 \mathrm{~m}$. By the eleventh year of the new benthic community succession, Abra was found in $100 \%$ of the samples. Its settlement density increased to average $506 \pm 116.2$ indivs $\cdot \mathrm{m}^{-2}$, at a biomass of $44.5 \pm 15.3 \mathrm{~g} \cdot \mathrm{m}^{-2}$. The density and biomass indices in the Abraaccompanying polyhaete Nereis and mollusc Cerastoderma appeared to grow or remain sufficiently high (Figure 4). By that time, the community had been comprised of 10 species of which $A$. ovata, with maximum density of 810 indivs $\cdot \mathrm{m}^{-2}$, was absolutely dominant.

After 1994, the sea level became stable or decreases slightly. The development of the Abra ovata community continued in the new marine area. At a depth of $0.5 \mathrm{~m}$, Abra remained absolutely dominant (among other 5 - 6 species), showing a $100 \%$ occurrence rate, a maximum density of 933 indivs $\cdot \mathrm{m}^{-2}$ and a biomass of $83.97 \mathrm{~g} \cdot \mathrm{m}^{-2}$. In the western and the seaward parts of Sulaksky Bay, at a depth of $2 \mathrm{~m}$, the abundance of Abra to equal 1856 indivs $\mathrm{m}^{-2}$, at a biomass of $241.28 \mathrm{~g} \cdot \mathrm{m}^{-2}$, the density of Nereis and Cerastoderma here being in excess of 100 indivs $\cdot \mathrm{m}^{-2}$. In all, the species richness of the community had increased by as much as half. 


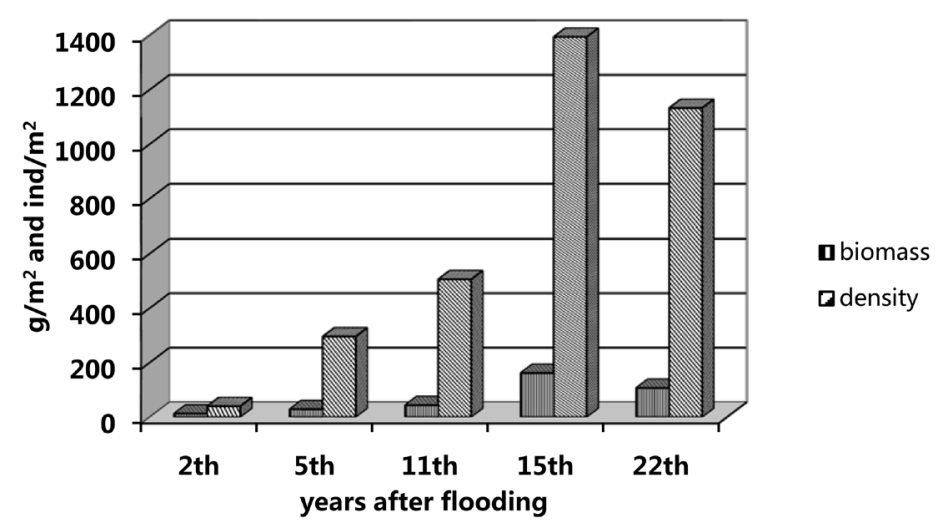

Figure 3. Changes in maximal the settlement density and biomass of mollusc Abra ovata in the during of succession of the community Abra ovata.

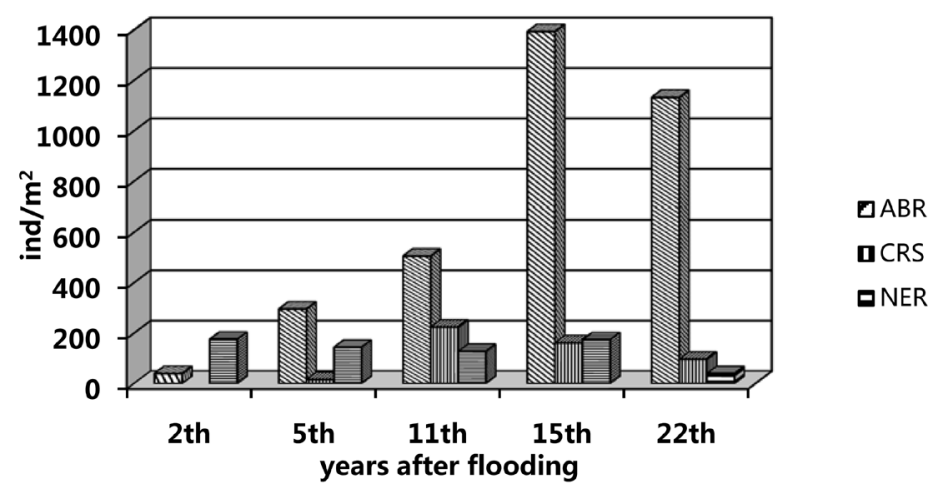

Figure 4. Variation in mean of population density of first colonists. CRS: C. glaucum, NER: N. diversicolor, ABR: A. ovata.

The beginning of 2000th has witnessed the Caspian Sea level gradually falling. The marine conditions in the flooded part of Sulaksky Bay apparently remaining, the composition and structure of the Abra ovata community appear to have undergone notable changes. On shallow littoral sites $(0.1$ to $0.3 \mathrm{~m})$, where the molluscs $A$. ovata, C. glaucum and the polychetes $N$. diversicolor had been common to abundant five years back (1996), their density dropped by a factor of 4 to 6 . In 2001, the maximum density of $A b r a$ equaled 80 indivs $\cdot \mathrm{m}^{-2}$, at a biomass of $3.04 \mathrm{~g} \cdot \mathrm{m}^{-2}$. The occurrence rate of C. glaucum (at a density of 8 indivs $\cdot \mathrm{m}^{-2}$ ) diminished by one half. At a depth of $0.5 \mathrm{~m}$, the qualitative composition of the community Abra ovata remained mainly unchanged, but its quantitative and structural characteristics had altered considerably. This mollusc retained absolute dominance (maximum of 1280 indivs $\cdot \mathrm{m}^{-2}$ ). The occurrence rate of Cerastoderma decreased by half, while its settlement density increased 1.2 - 1.5 times. The density of polychetes reduced from $67-80$ to 40 indivs $\cdot \mathrm{m}^{-2}$. There appeared numerous empty shells of Abra and Cerastoderma, from 680 to 1120 indivs $\cdot \mathrm{m}^{-2}$. Late in July 2001, a decrease in silting of sandy sediment fractions was observed at a depth of $0.8-1.2 \mathrm{~m}$. The thick clayey silts, characteristic of the most of the Bay's land-end, came to be covered with slightly silty fine- and medium-grained sand. Some decrease in the density of Abra, Cerastoderma and Nereis was observed in the northeastern part of the Bay. There was a sharp increase in the number of empty shells of bivalve molluscs, reaching 4000 to 5000 indivs $\mathrm{m}^{-2}$. In the more seaward and in the western part of the Bay, at a depth of $1.08 \mathrm{~m}$ (previously $2-2.5 \mathrm{~m}$ ), the density of the dominant $A$. ovata rose to 2040 indivs $\cdot \mathrm{m}^{-2}$, while its biomass was $191.8 \mathrm{~g} \cdot \mathrm{m}^{-2}$, showing a drop by a factor of 1.25 . The polyhaetes showed a threefold decrease in density $\left(40\right.$ indivs $\left.\cdot \mathrm{m}^{-2}\right)$. The bivalves Cerastoderma, however, managed to preserve their subdominant role $\left(120\right.$ - 320 indivs $\left.\cdot \mathrm{m}^{-2}\right)$.

Overall, the species composition of the community has doubled (see Table 1) as compared to the initial phases of succession observed seven years ago [16]. There has been an increase in density of the bivalve molluscs, such as Mytilaster lineatus, Hypanis minima ostroumovi, Didacna trigonoides (36, 40, up to 12 indivs $\cdot \mathrm{m}^{-2}$, 
Table 1. Composition and structure the Abra ovata macrobenthos community in Sulakskii Bay, at depths of 0.1 to $2 \mathrm{~m}$; Bi: Bivalvia, Ga: Gastropoda, Po: Polychaete, Ci: Ciripedia, Am: Amphipoda, De: Decapoda, Br: Bryozoa, Al: Algae, He: Sea grass; a: mean settlement density, indiv $\cdot \mathrm{m}^{2}$; b: mean biomass, $\mathrm{g} / \mathrm{m}^{2} ; \mathrm{m}_{\mathrm{M}}$ : mean error; $(+)$ : species that were not registered quantitatively.

\begin{tabular}{|c|c|c|c|c|}
\hline Taxon & Taxonomic group & $\begin{array}{c}1994 \\
\mathrm{a} \pm \mathrm{m}_{\mathrm{M}} \\
\mathrm{b} \pm \mathrm{m}_{\mathrm{M}}\end{array}$ & $\begin{array}{c}1996 \\
\mathrm{a} \pm \mathrm{m}_{\mathrm{M}} \\
\mathrm{b} \pm \mathrm{m}_{\mathrm{M}}\end{array}$ & $\begin{array}{c}2001 \\
\mathrm{a} \pm \mathrm{m}_{\mathrm{M}} \\
\mathrm{b} \pm \mathrm{m}_{\mathrm{M}}\end{array}$ \\
\hline \multirow[t]{2}{*}{ Abra ovata (Philippi) } & $\mathbf{B i}$ & $341 \pm 63.3$ & $378 \pm 69.3$ & $752 \pm 30.1$ \\
\hline & & $33.9 \pm 6.3$ & $49.14 \pm 9.2$ & $78.6 \pm 4.0$ \\
\hline \multirow[t]{2}{*}{ Cerastoderma glaucum (Poiret) } & $\mathbf{B i}$ & $51 \pm 9.4$ & $162 \pm 30.1$ & $128 \pm 11.4$ \\
\hline & & $16.4 \pm 2.9$ & $29.2 \pm 5.2$ & $19.6 \pm 1.7$ \\
\hline Hypanis vitrea (Eichw.) & $\mathbf{B i}$ & - & + & 240 \\
\hline H.minima ostroumovi (Logv.et Star.) & $\mathbf{B i}$ & - & - & 40 \\
\hline Mytilaster lineatus (Gmelin) & Bi & - & + & 36 \\
\hline Dreissena polymorpha (Pallas) & Bi & - & - & ed. \\
\hline Didacna trigonoides Pallas & Bi & - & - & 40 \\
\hline Pyrgula ulskii (Cles. et Dyb.) & Ga & - & + & + \\
\hline Horitia marina (Logv. et Star.) & Ga & - & - & + \\
\hline Theodoxus pallasi Lindcheim & Ga & - & - & + \\
\hline \multirow[t]{2}{*}{ Nereis diversicolor (Mueller) } & Po & $140 \pm 25.9$ & $164 \pm 30.4$ & $58 \pm 5.1$ \\
\hline & & $3.5 \pm 0.6$ & $11.5 \pm 2.2$ & $4.1 \pm 0.8$ \\
\hline \multirow[t]{2}{*}{ Balanus improvisus Darwin } & $\mathbf{C i}$ & + & $227 \pm 47.2$ & $287 \pm 53.7$ \\
\hline & & & $24.9 \pm 4.6$ & $31.5 \pm 4.9$ \\
\hline Pontogommarus maeoticus (Sow.) & Am & + & + & + \\
\hline \multirow[t]{2}{*}{ Rhithropanopeus harrisii (Gould) } & De & + & $23.8 \pm 4.4$ & + \\
\hline & & & $16.1 \pm 3.1$ & \\
\hline Conopeum seurati El. et Sol. & $\mathrm{Br}$ & - & - & + \\
\hline Cladophora sericea (Hunds.) & Al & + & + & + \\
\hline Enteromorpa interstinalis (L.) Link. & Al & + & + & + \\
\hline Acrochaeticus sp. & Al & + & + & + \\
\hline Polysiphonia sp. & Al & + & - & \\
\hline \multirow[t]{2}{*}{ Zostera sp. } & He & - & + & $40 \%-60 \%$ coverage \\
\hline & & & $\overline{99.7} \pm \overline{11.8}$ & 877.6 \\
\hline Ruppia sp. & He & - & & $60 \%-80 \%$ coverage \\
\hline
\end{tabular}

respectively), of which only single individuals used to occur in the past. Some other colonists, such as second species of gastropods $H$ vitrea (up to 240 indivs $\cdot \mathrm{m}^{-2}$ ), sporadic gastropods Thejdoxus pallasi and bryozoans Conopeum seurati, have made their appearance. Species variety became the greatest on all depths for all time of existence of the Abra ovata community (Figure 5).

\section{Discussion}

The bivalve mollusc A. ovata is distinguished by a high annual reproductive potential within the period between April and October, and a rather high growth rate before attaining maximum size. The efficient mass dispersal of its meio- and macrobenthic larvae is another, no less important feature of Abra biology [6] [8] [9] [11] [12]. All this allows the mollusc to quickly restore its population number (after summer grazing by sturgeon fishes), and to succeed in expanding its habitation area.

It took Abra ovata 6 to 7 years to be successfully acclimatized following its artificial introduction into the Caspian Sea. In those years it occupied new places of dwelling in already existing sea conditions of Caspian Sea [15]. During its third year on the newly flooded area of Sulaksky Bay (where sea conditions did not exist before flooding), A. ovata already demonstrated a threefold superiority in biomass over the first settler, Nereis, and after 5 to 6 years, it gained absolute dominance amongst all the later invaders [16]-[20].

In the 15 - 16 years that followed, Abra remained dominant in spite of the growing diversity and number of new dwellers, which totaled in excess of 21 species in the new community [20]-[22]. The first succession phases of Abra ovata community have been clearly outlined as early as within 6 to 7 years after the flooding began. The species composition ( 3 - 5 species) of this community remained practically unchanged. It is only the quantitative structure that was tangibly affected by the realignments within the community, which were related primarily to the lithological patchiness of the bottom sediments inhabited by the species. The next succession phase in the community Abra ovata (in the $9^{\text {th }}$ to $10^{\text {th }}$ years of its existence) featured a more dynamic development. First, 


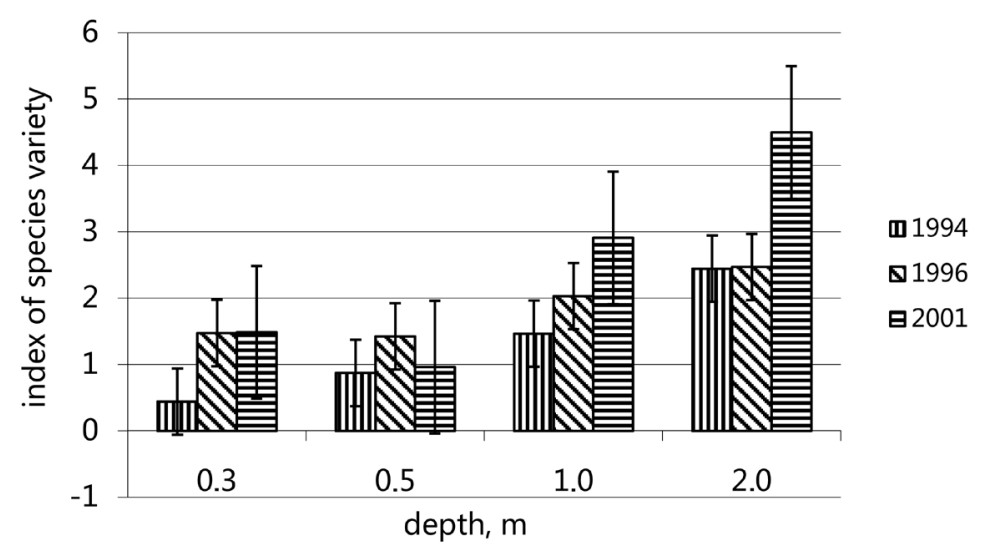

Figure 5. Species variety on various depths in the during of succession community Abra ovata.

there was a two-fold increase in the species richness, which has amounted up to 10 species. Second, the settlement density of the pioneer species increased 1.5 - 3 times, and, besides, the molluscs Abra and Cerastoderma have settled at depths of $0.3-0.1 \mathrm{~m}$. And, finally, there was a newly arisen settlement of seagrass Ruppia, with its stems serving as a substrate and a refuge for the spat of barnacles, mussels and crabs [20] [21].

After nearly twenty years of marine conditions persisting in Sulaksky Bay, the community Abra keeps on developing. There is a marked build-up in variety of species: the number of species, of which only single individuals used to occur in the past, is growing. The density and the frequency of occurrence of the dominant $A$. ovata and C. glaucum, which were growing during 15 years, have become subject to seasonal changes similar to those occurring in the stable conditions of Middle Caspian [4]. Earlier, their density was 1.3 - 1.5 times higher, even with regard for variations, than the long-term density of these bivalve molluscs for the entire Dagestan area of Caspian Sea. Annual and seasonal fluctuations of density A. ovata, C. glaucum and N. diversicolor are usually observed in the Caspian Sea. The seasonal decrease in the abundance and biomass of these species occupying the first three places in the feeding spectrum of sturgeon is directly linked with their consumption by sturgeon in August [4] [14]. At this time of the year, frequency of occurrence of A. ovata in the Middle Caspian Sea decreases to $43 \%$. Earlier, in Sulaksky Bay, the frequency of occurrence was not less than $90 \%$ for A. ovata and $100 \%$ for $N$. diversicolor. At present, the frequency of occurrence of the bivalve is $60 \%-70 \%$, and that of polychaetes about $50 \%$.

Multiple empty shells of Abra and Cerastoderma (4 - 5 thousand pieces $/ \mathrm{m}^{2}$ ) have appeared as a result of predation on molluscs by the sturgeon in late July-early August and of natural mortality. The seasonal reduction in the number and biomass of Abra and other similar bivalves, which hold the lead in the food spectrum of many fishes, is linked with their consumption during summer-autumn months [4] [12]-[14].

The biocenosis of Abra ovata in the Middle Caspian is composed of 20 to 25 species of macrobenthos [3] with evident prevalence of the Mediterranean invaders A. ovata, C. glaucum and $N$. diversicolor. Since the flooding began, 21 zoo-and phytobenthic species (see Table 1) have settled in Sulaksky Bay, including the above three dominants, that were, in different past years, introduced into the Caspian Sea to become the main components of all the stable biocenoses of the Caspian soft bottom grounds [4] [22] [23]. A. ovata is a constant component in 10 of the 14 Caspian biocenoses, being, in terms of density or biomass, a first- or second-order dominant in $40 \%$ of them.

The establishment and development of the community Abra ovata in Sulaksky Bay with its time-variant composition and structure is a striking example of the primary succession [24] of a marine benthic community. Its initial and subsequent development stages were determined by the new dwellers, Mediterranean-resident species A. ovata, $N$. diversicolor and C. glaucum. By feeding behaviour and habitat, these species do not compete among themselves or with other species of Caspian biocenoses.

It was the tolerance of the Sulaksky pioneer settlers for later colonists (macrophytes, mytilids, crustaceans and other organisms) that governed the development of the first succession stage. This fact was encouraging for rather a prompt settling of other numerous species and for the establishment in the shallow part of Sulaksky Bay of a new Abra ovata community, close in its character to the stable Middle Caspian soft-bottom biocenosis [22] 
[23] [25]. The determining influence of resident species on initial phases of succession and on its further development has been shown in nature and in different experiments [26]-[28]. Further succession phases may often depend on the so-called pasture species [29]-[31], which serve as food for species of a higher trophic level. During 12 - 15 years of its development, the community Abra ovata was showing a steady growth in number of pioneer settlers. They increased their settlement density and were occupying all depth levels ranging between 2 and $0.1 \mathrm{~m}$. The pattern of evenly distributed pioneer colonists may be temporarily enhanced in subsequent succession stages if the ability of later species to recruit in the presence of an early colonizer is inversely related to the later species' abilities to compete among themselves [28]. In 2001, a significant fluctuation in the population number of the three original species was observed resulting from grazing by sturgeon in late July-early August.

The next succession stage in Abra ovata communities of Sulaksky Bay does not quite agree with the pattern typical of solid substrates including experimental plates [32]-[35]. On the one hand, the community development supports the tolerance model: the pioneer Abra, in spite of being dominant during all the succession stages, do not oppose settling of other multiple colonists; on the other hand, it agrees with a facilitation model where the abundance of the original settlers, the grazing species, provokes the appearance of sturgeon. Because of the variety of potential effects, arising due to introduction of different resident species (stochastic or deterministic events), the species composition at early stages of a community development may indirectly affect the species composition at later stages in increasingly complex ways [27] [36]. Depth of dwelling in Sulaksky Bay after 10 11 years of its flooding did not vary essentially (see Figure 2). Fluctuations of depth in the range of $0.5 \mathrm{~m}$ occurred within 10 years. These fluctuations could not cause sharp or essential changes in a mode of wave influences taking into account closed of Sulaksky Bay. A determining condition of succession of Abra ovata communities were time and biotic factors. Density of species dominant was constantly growing at all depths. The species variety increased too (Figure 5 and Figure 6). For example, at the initial phases of succession, sessile organisms (mussels, barnacles, bryozoans and others) could not settle on silt and sandy bottom. With the emergence of sufficient number of empty shells as well as bulging parts of live bivalves, new colonists in need of solid substrate, began settling down. In the course of succession, species richness and diversity of invertebrate forms was growing thus changing the biotic factors. Direct interaction between early or subsequent dwellers, and/or indirect effects of this interaction made the abiotic environment more or less favourable for later colonists.

\section{Conclusion}

At the very first phases of succession, it was possible to forecast its further development pattern as an increase in the number of the first residents, mastering by them of new biotopes and some growth in biodiversity. In addition, these forecasts have in many aspects been confirmed [20]-[22] [25]. At the present development stage, the complexity and unpredictability of further course of succession and variations in its models in Sulaksky Bay are likely to increase with each stage, since casual and historic events (the sea level is falling again) affect the probability of any specific interaction between biotic and abiotic factors.

\section{Acknowledgements}

This work was supported by the RFFI grant "Succession in Marine Benthic Communities” No-99-04-48071.

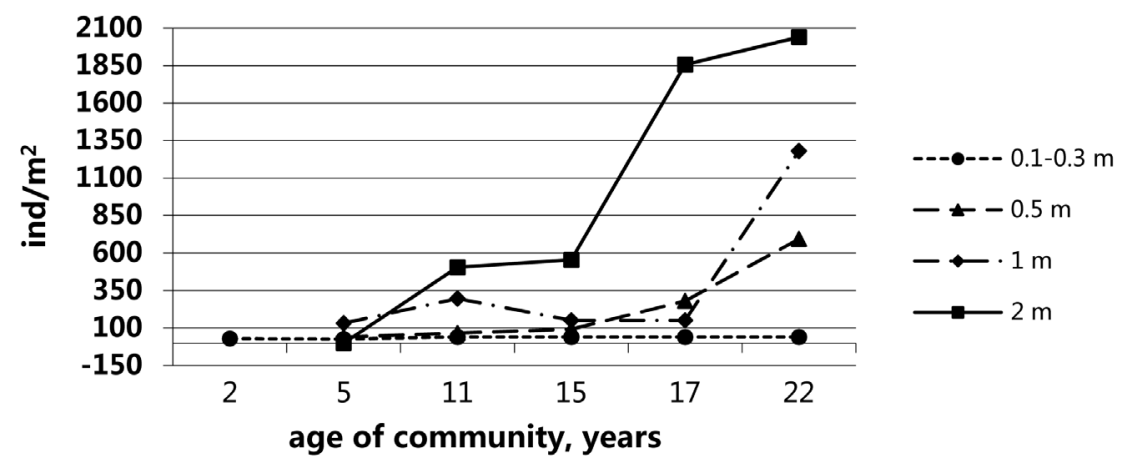

Figure 6. Settlement density of mollusc Abra ovata on various depths in the during of succession community Abra ovata. 
The author is grateful to Dr. R.D. Magomedov (Manager, Division of Marine and Land Ecology), Dr. V.A. Zaiko (Senior Researcher, Caspian Institute of Biological Resources), for help in arranging the expedition; Dr. V.V. Gulbin (Institute of Marine Biology) for comments on the manuscript; T.V. Titlyanova (Institute of Marine Biology), for identification of macrophytes and T.N. Koznova for translating the text into English.

\section{References}

[1] Aligajiev, A.G. (1989) Biologicheskie resursy Dagestanskogo rybokhozyaistvennogo raiona Kaspia. Dagknigoizdat, Makhachkala.

[2] Mironenko, O.E. (2008) Species Are Introduced Species in the Caspian Sea. Komsomolec Caspia, 79.

[3] Recluz, C. (1843) Monographie du genre Syndosmia. Revue Zoologique, 359-369.

[4] Aligajiev, A.G. (1963) Resettlement of Sindesmia ovata in Dagestan Waters of the Caspian Sea. Doklady Akademy Sciences, 149, 707-710.

[5] Gléemarec, M. (1964) Le genre Abra sur les côtes atlantiqies de Bretagne. Systématique et écologie. Journal of Conchylium, 14, 15-28.

[6] Denis, P. (1981) Croissance linéaire, croissance pondérale et période de reproduction de Abra ovata, mollusque pélecypode, dans la orientale du Golf du Morbian. Cahiers de Biologie Marine, 22, 1-9.

[7] Kevrekidis, Th. and Koukouras, A. (1992) Population Dynamics, Growth and Productivity of Abra ovata (Mollusca, Bivalvia) in the Evros Delta (North Aegean Sea). International Review of Hydrobiology, 77, 291-301. http://dx.doi.org/10.1002/iroh.19920770209

[8] Sprung, M. (1994) Observation on the Life Cycle of Abra ovata on an Intertidal Mud Flat in Portugal. Journal of the Marine Biological Association of the United Kingdom, 74, 919-925.

[9] Vorobyev, V.P. (1949) A Benthos of Azov Sea. In: Trudy Azovo-Chernomorskogo Inst. morsk. rybnogo hozyaistva i okeanografii, Izd. Pischevaya promyshlennost. M.

[10] Falcão, M.M., Pissarra, J.L. and Cavaco, M.H. (1985) Características físicas e químicas da Ria de Faro-Olhão. Ralatório INIP, 61, 1-24.

[11] Osadchikh, V.F. (1963) The Role of New Dwellers in the Benthos of the North Caspian Sea. Zoologicheskii Zhurnal, 62, 990-1004.

[12] Romanova, N.N. (1977) Seasonal Changes of Quantitative Distribution and Some Ecological Features of Abra ovata (Mollusca, Bivalvia) near the Midwestern Coast of the Caspian Sea. Zoologicheskii Zhurnal, 56, 1150-1160.

[13] Rainer, S.F. (1985) Population Dynamics and Production of the Bivalve Abra alta and Implication for Fisheries Production. Marine Biology, 85, 253-262. http://dx.doi.org/10.1007/BF00393245

[14] Dvornikov, P.I. (1989) Pitanie osetra I sevryugi v zapadnoi chasti Srednego Kaspia. In: Biologicheskie resursy Kaspiiskogo moray, DagFAN, Makhachkala, 68-83.

[15] Saenkova, A.K. (1956) New in Fauna of Caspian Sea. Zoologicheskii Zhurnal, 35, 678-679.

[16] Latypov, Y.Y., Gulbin, V.V. and Yakovlev, Y.M. (1995) Rise of the Caspian Sea Level and Its Influence on Nearshore Ecosystem. Biologia Morya, 21, 281-285.

[17] Khublaryan, M.G. (1995) The Caspian Sea Phenomenon. Herald of the Russian Academy of Sciences, 65, 616-630.

[18] Latypov, Y.Y. (2004) Abra ovata Community Succession on Soft Soil Once Again Flooded in Caspian Sea. Ecology, 4, $1-7$.

[19] Latypov, Y.Y. and Yakovlev, Y.M. (1998) The Succession of the Bivalve Abra ovata Community in Sulaksky Bay, the Caspian Sea. Biologia Morya, 24, 250-253.

[20] Malinovskaya, L.V. and Zinchenko, T.D. (2010) Long-Term Dynamics of Invasive Species Hediste diversicolor and Abra ovata (Philippi) Biomass Muller in the Northern Caspian Sea. Russian Journal of Biological Invasions, 4, 32-43.

[21] Schiganova, T.A. (2009) Chuzherodnye vidy v ecosystemah yuzhnyh morei evrasii. Author's Abstract of Dissertation, Moscow, $57 \mathrm{p}$.

[22] Latypov, Y.Y. (1977) The Level of Caspian Sea Changes Again. Herald of the Russian Academy of Sciences, 67, 10821087.

[23] Latypov, Y.Y. (2002) New Phase of Succession of Bivalve Community Abra ovata in Sulaksky Bay of the Caspian Sea. Biologia Morya, 28, 459-462.

[24] Kasymov, A.G. (1987) Zhivotnyi mir Kaspiiskogo moray. Izd. “Elm”, Baku.

[25] Abdulmedžidov, A.A. (2013) Ecological and Biological Characteristics of Abra ovata in Daghestan’s Caspian Coastal 
Zones. In: Abdulmedžidov, A.A. and Gapisova, W.A., Eds., News DSPU, A Series of Natural and Exact Sciences, 32-35.

[26] Latypov, Y.Y. (1996) Caspian Sea Level: Catastrophe, Phenomena or Usual State? Herald of DVO RAN, 5, 29-35.

[27] Clements, F.E. (1916) Plant Succession: Analysis of the Development of Vegetation. Carnegie Institution of Washington Publication Sciences, 242, 1-512. http://dx.doi.org/10.5962/bhl.title.56234

[28] Russ, G.R. (1980) Effect of Predation by Fishes, Competition, and Structural Complexity of the Substratum on the Establishment of Marine Epifaunal Community. Journal of Experimental Marine Biology and Ecology, 42, 55-69. http://dx.doi.org/10.1016/0022-0981(80)90166-5

[29] Osman, R.W. (1982) Artificial Substrates as Ecological Islands. In: Cairns, J., Ed., Artificial Substrates, Annales Arbor Science Publication, Ann Arbor, 71-114.

[30] Breitburg, D.L. (1985) Development of a Subtidal Epibenthic Community: Factors Affecting Species Composition and the Mechanisms of Succession. Oecologia, 65, 173-184. http://dx.doi.org/10.1007/BF00379215

[31] Dugging, D.O. (1980) Kelp Beds and Sea Otters: An Experimental Approach. Ecology, 61, 447-453. http://dx.doi.org/10.2307/1937405

[32] Woodin, S.A. (1981) Disturbance and Community Structure in a Shallow Water Sand Flat. Ecology, 59, $1052-1066$. http://dx.doi.org/10.2307/1937004

[33] Farrell, T.M. (1991) Models and Mechanism of Succession: An Example from a Rocky Intertidal Community. Ecological Monographs, 61, 95-113. http://dx.doi.org/10.2307/1943001

[34] Connell, J.H., Noble, I.R. and Slatyer, R.O. (1987) On the Mechanisms Producing Successional Change. Oikos, 50, 136-137. http://dx.doi.org/10.2307/3565410

[35] Connell, J.H. and Slatyer, R.O. (1977) Mechanisms of Succession in Natural Communities and Their Role in Community Stability and Organization. The American Naturalist, 111, 1119-1143. http://dx.doi.org/10.1086/283241

[36] Breitburg, D.L. (1984) Residual Effects of Grazing: Inhibition of Competitor Recruitment by Encrusting Coralline Algae. Ecology, 65, 1136-1143. http://dx.doi.org/10.2307/1938321 